\title{
Aromanian's Language and Culture
}

\author{
Dr. Ema Kristo \\ Faculty of Humanity, "Aleksandë Xhuvani" University, Elbasan/ Albania \\ Ema.kristo@uniel.edu.al
}

Doi:10.5901/jesr.2014.v4n4p237

\section{Abstract}

In the end of 18th century, a population, who had special characteristics and a key distinctive element of Latino-phonetics, draws attention to some European researches. Aromanian's (Vlachs') origin and language have been an object of research for many well-known scientific institutions in Balkan, Europe etc. The literature, which was inherited by Latin speakers in Balkan Peninsula, was an important and valuable source of information until the end of 18th century. One of the first researches in this period, Johan Tunman (1774) expresses some discomfort of research absence in this field. It is needed some decades that researches should not be ascertainments, but they could be based on evidences and arguments. Researches on Vlachs and their language (Aromanian) have undertaken a new development nowadays. In general, they represent opinions and hypotheses in relation to key problems such as ethnical and lingual origin of this population that converge in similar theses and opinions. The object of the research in this article is a historical point of view of Vlachs and their language.

\section{The Aromanians in the Reports of English and French Traveler of the 18th and 19th Century}

Aromaninas are a population that lives in some places in the Balkans such as Albania, Greece, Macedonia, Bulgaria and Serbia.

211 years ago, in 1774, in one of his books, the great researcher Johann Thunmann published in relation to history the following:

"No other population in any part of the world in which we live in, is not as unknown for us, West Europeans in relation to origin, history and language compared to Albanians and Vlachs. They are main peoples, old and important peoples who every historian would like to know. Their history would complete huge gaps in ancient and modern history of Europe."1

200 years later, after Thunmann had written this, the new Austrian historian Max Demeter in his book Aromanian's Issue, which was published in Vienna in 1074, expresses the same discomfort in relation to Vlach's population. ${ }^{2}$

In these two citations, it is included the essentiality of Aromanian's issue - the unfair luck of an ancient population and their rich culture. ${ }^{3}$

Although scientific researches in relation to Aromanians date back in the second half of $19^{\text {th }}$ century, it should not be neglected the fact that Aromanians are mentioned a lot of times before, in travelers' chronics from central and Western Europe. In this context, it is not included only interesting facts of unknown peoples and their customs and traditions, but also valuable observations in relation to Arumanian's population and their culture. There are introduced some of the main characteristics of these chronics in the following lines: ${ }^{4}$

First of all, it is mentioned that English and French travelers lived as diplomats in central and Southern Europe. During their staying, they have been in contact with foreign peoples and cultures firstly because of their curiosity they studied the history, customs and traditions of these peoples for example, Aromanians, Albanians, Greeks and Serbs.

It is also mentioned the French researcher F.C.H. L. Pouqueville who has written his creation in five volumes "Voyage dans la Grèce". As it could be read in the coverpage of this book - Ancien consul - général de France près d'Ali, pacha de Janina; correspondant de l'Académie Ionienne de Corcyre etc. ${ }^{5}$

\footnotetext{
1 Thunmann, J. 1774

2 "Was für die Albaner zweihundert Jahre später nicht mehr gilt, das trifft umso mehr auf das kleine, weihin unbekannte Volk der Vlachen oder Aromunen zu, dem es im Zeitalter des Nationalismus nicht beschieden war, Gleichberechtigung oder gar Eigenstaatlichkeit zu erlangen. Bei der Aufteilung der Europäischen Türkei unter den Balkanstaaten sind die Aromunen nicht nur leer ausgegangen, sie haben dabei auch ihre nationale Einheit eingebüßt".

${ }^{3}$ Barba, V. 1987, p.1

${ }^{4}$ Dahmen, W. 1987, p.107

5 Ibid
} 
Secondly, it is mentioned E.M. Cousinéry, who was general consul in Selanic, and traveled in regions where Aromanioans lived.

Moreover, it is mentioned English travelers who in the beginning of $19^{\text {th }}$ century traveled in the Balkans. They are mainly people who were influenced by romantics and traveled through Greece and in this context they contacted Aromanians. It is the poet Lord Byron who from 1809 to 1811 crossed Southern Europe, orient and passed some time in Yanina.

In his epos Childe Harold's Pilgrimage it is described a picture of Yanina's inhabitants and its surroundings where it is easily distinguished that it is spoken about Aromanians, even though it is not mentioned directly. The following lines are an extract from note 52, second lyric of Childe Harold's Pilgrimage ${ }^{6}$

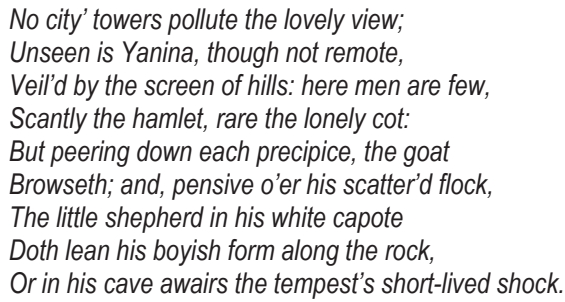

Aromanians grabbed attention to travelers by their traditional form of economy, pasture etc. it is normal that for English and French travelers this was something special that should be noted in their chronics.

For Instance, Martin Leake describes in details how sheep moving, producing pipes which has been a characteristic of Aromanians' shepherds. "In the mountain pastures in every part of Greece, the shepherds may be heard ... pouring forth a wild melodious strain from their pipes, amidst the murmuring of the waters, and the whispering of the wind through the trees."7

Simple Aromanians' habitation are described by Stuart Glennie: "There was neither chair nor table, but the floor was covered with thick, richly coloured rugs, the handwork of the household; and along the wall on either side of the hearth, and under the windows, was a range of comfortable cushions. All the wall opposite the hearth was occupied by a most artistically designed and elaborately carved wardrobe, also of native workmanship."8

This description is enriched with Aromaninans' characteristic clothes description and their way of life in cities such as Yanina, Vlacho-Clissura and Moschopolis.

Moreover, it is described Aromanians' activities as excellent merchants and their trade relations up to central Europe. We could mention Mary Adelaide Walkers' note in Through Macedonia to the Albanian Lakes (1864): "Among the Christian population of Monastir the Vlachs rank the highest for commercial enterprise, industry, and intelligence." Pouquevielle's descriptions in relation to how herd move and trans-human forms of life are really interesting as well.

\section{Aromaninans' Name and Origin}

As it is for the most part of Balkan's peoples and languages, even for Aromanians and their language, the problem of origin and especially their historical aspect is a debatable issue and it is not definitely resolved. The difficulties that this problem faces could be concluded in these issues: the connections of Aromanians and their language with Romans and their language, connections with ancient Balkan's peoples (Daco-Tracs, Greeks and llirs) and their languages, connections with Aromanians' people and their new language..$^{10}$

Researchers, historians or linguists have worked out the informative materials that have inherited from ancient time and they have concluded the following ideas which could be grouped into three basic theories for Vlachs' origin:

I. Vlachs are descendants of Roman colonies.

II. Vlachs came in Macedonia, Thessaly and Epir from places of Traco-llir region.

III. Vlachs are natives which were Latinized. ${ }^{11}$

\footnotetext{
${ }^{6}$ Byron, L. 1975

${ }^{7}$ Martin Leake, W. 1967, p 290.

${ }^{8}$ Cited from Dahmen, W. 1987, p.109

9 lbid.

${ }_{10}$ Riska, A.p.75

${ }^{11}$ Compare Poci, S. 2009,p.12
} 
These theories represent the whole experience for Vlachs starting from medieval opinion in empire chronic writings to nowadays evaluations based in conditions of developed historical-linguistic science.

The first theory is represented by for example the French Cousinéry who explains precisely: "Cette population est purement romaine". Then he emphasizes more this fact by providing Aromanians' answer: "leur langue empêche de les (=Aromanians) méconnaître; ils parlent toujours latin, et si on leur demande, de quelle nation êtes vous? Ils réspondent avec fierté Rouman"12

Based on second theory, the first one who thinks that Vllachs moved down in the south of Balkan Peninsula from north of Trak region is Byzantine chronic writer Kekaumenos who becomes the main resource that supports recent arguments of this theory.

The theory of native origin of Vlachs in places where they live nowadays is generally supported by modern researches who have found interesting evidences and supportive arguments in favor of this opinion.

As it is discussed about the origin of Aromanian people, the possibilities to explain Aromanian language are some ${ }^{13}$. It could be represented in the following groups:

A. Aromanian language refers to directly to Vulgar Latin language that was spoken in the Balkan during Roman Empire. One of the hypotheses of Aromanian's people origin is related to the fact that we should remember the hypothesis that Aromanians are Roman colonies.

B. Aromanian language refers to one of Romanian dialects that for different reasons, was separated from the trunk and started an independent life in the Balkans. This is the most supported hypothesis an in general refers to scientific opinion. The main supporters of this opinion are Romanian linguists.

C. Aromanian language is a result of partly Romanization process (in quantitative aspect) in one of the Balkan's languages. This idea would suppose partly Latinizing of llirs or Greeks and a compulsory autochthony of Aromanians that was protected by Capidani, Papahagi, Caragiu, Saramandu, Poghircu. In Greece, nowadays, the main supporter of this idea is the researcher Achille Lazarou. Lazarou has dealt with this issue more than once tries to discuss that Aromanians are Latinized Greeks. According to him, this process happened in Thesali14.

The most acceptable hypothesis would be considered in general the thesis that Aromanian Language a geographically separated variant of Romanian. Historical conditions of the Balkan normally support Miklosich's opinion that Aromanian were separated from the trunk during Slav congestion, but the common trunk should not mean above Danup ${ }^{15}$.

\section{Actual Geographical Distribution of Aromanian's}

During Medieval period, geographical distribution of Aromaninan was situated in Mount range Pints. Nowadays, only a part of population is situated there.

The most important reasons where Aromanians are distributed nowadays are: in Greece (Pints, Vérmion, Olimpi and Páiko, Epir coast, the flat area of Selanik and Macedonia. In Albania: Lunxhëri Highland, Valamarë, Moravë, Kolonjë and Dangëlli, areas of Devoll River, Shkumbin and Vjosë, flat area of Vurgut and Myzeqe as well. In Macedonia: Pelagoni including the flat area of Baba, areas in the north of Vardarit. In Bulgaria: the highland of Western Rodopëve, Pirin and Rila; in Rumania: Dobrusha; in Turkey Trakias region. Moreover, Aromanians moved in Diaspora (during $18^{\text {th }}$ century and the beginning of $19^{\text {th }}$ century) in urban habitation in Egypt, Hungary and later in France, Poland and Germany; during later Diaspora (emigrants of the end of $19^{\text {th }}$ century and $20^{\text {th }}$ century) they moved in places in Central Europe, North America and Australia ${ }^{16}$.

\section{Ethnonyms about Aromanian (Observations on Ethnonyms used to Mark Aromanias)}

To mark this ethnic group are used two ethnonyms, Aromanian or Vlach. These terms are both exonyms; the first one is a modern term, while the second one is a medieval term. The Aromanians call themselves Armân, Rrâmân or Makidon. So in Albania, the most common form is rrămăn (in singular), in Greece both armăn and rrămăn, in Republic of Macedonia,

\footnotetext{
${ }^{12}$ Cited from Dahmen, W. 1987, p.110

${ }^{13}$ Riska, A. p. 78 pp.

${ }^{14} \mathrm{lbid}$.

${ }^{15} \mathrm{l}$ bid.

${ }_{16}$ Kahl, Th. 1999, p. 22p.
} 
Serbia and Bulgaria armăn, in Romania armăn and makidon. ${ }^{17}$

The list of the terms denoting this ethnic group, either totally or in part (without pretending to have full information about ethnonyms or nicks that mark certain groups of Aromanians in other countries where they live) result in: Aromanian, Vlach, Koutsovlachs, Frashariotes, Arvanitovlachs, Tsintsar (also spelled tzintzar, cincar or similar) Mavrovllah, Chobans (Shepherd), Karacovalt, Llaci-Faci (in Albania). ${ }^{18}$

They also, have several nicknames depending on the country where they are living.

For example:

- In Greece they are nicknamed Koutsovlachs (this term is used with a negative charge) or Arvanitovlachs meaning "Albanian Vlachs" referring to their place of origin. ${ }^{19}$

- In the South Slavic countries, such as Serbia, Republic of Macedonia and Bulgaria, the nicknames used to refer to the Aromanians are usually Vlasi and Tsintsarwhich is derived from the way the Aromanians pronounce the word meaning five, tsintsi. ${ }^{20}$

- Albanians use their own nicknames to refer to the aromanians, such as; Vllah/Vlleh; and also as chobans. (Çoban meaning pastoral mountain folk and shepherd). The word stems from Turkish çoban, which means "shepherd". ${ }^{21}$

The ethnonym Shepherd is connected by the profession of farming, which has been one of the main economic activities of the Aromanians. As appellative it is used by all Balkan countries. The Greeks use also the terms çoban or çopan. ${ }^{22}$

\section{Bibliography}

Barba, V. (1987) Über die Aromunen, ihre Sprache und Kultur. In: Rohr, R. (Ed) Die Aromunen. Sprache - Geschichte - Geographie. Helmut Buske Verlag, Hamburg.

Byron, L. (1975) Childe Harold's Pilgrimage and Other Romantic Poems, ed. John, D. Jump.

Dahmen, W. (1987) Die Aromunen in den Berichten englischer und französischer Reisender des 18. Und 19. Jahrhunderts. In: Rohr, R. (Ed) Die Aromunen. Sprache - Geschichte -Geographie. Helmut Buske Verlag, Hamburg.

Kahl, Th. (1999) Ethnizität und räumliche Verteilung der Aromunen in Südosteuropa. Münstersche Geographische Arbeiten. Münster

Martin-Leake, W. (1967) Travels in Northern Greece. Amsterdam. Vol.1

Poci, S. (2009) Vllehtë. Historia dhe gjuha e tyre. Botimet Toena. Tiranë.

Riska, A. (2011) Trajtesa gjuhësore, Pegi, Tiranë.

Thunmann, J. (1774) Untersuchungen über die Geschichte östlichen europäischen Völker. Leizig

en.wikipedia.org/wiki/Aromanians

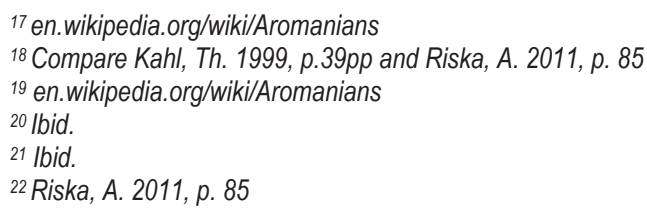

